\title{
eJRIEPS
}

Ejournal de la recherche sur l'intervention en éducation physique et sport

Hors-série $N^{\circ} 4$ | 2021

Actes de la $11^{\text {e }}$ Biennale de l'ARIS, Liège, 25-28 février 2020

\section{Redesigning the Pedagogies of Physical Literacy: Using Design Thinking as an innovation approach}

Repenser les pédagogies de la littératie physique: utilisation du design thinking en tant qu'approche d'innovation

Fiona C. Chambers

\section{(2) OpenEdition}

\section{Journals}

Electronic version

URL: https://journals.openedition.org/ejrieps/6208

DOI: 10.4000/ejrieps.6208

ISSN: 2105-0821

\section{Publisher}

ELLIADD

\section{Electronic reference}

Fiona C. Chambers, "Redesigning the Pedagogies of Physical Literacy: Using Design Thinking as an innovation approach", eJRIEPS [Online], Hors-série N 4 | 2021, Online since 10 June 2021, connection on 03 July 2021. URL: http://journals.openedition.org/ejrieps/6208 ; DOI: https://doi.org/10.4000/ ejrieps.6208

La revue eJRIEPS est mise à disposition selon les termes de la Creative Commons Attribution 4.0 International License. 


\section{Redesigning the Pedagogies of Physical Literacy: Using Design Thinking as an innovation approach}

Fiona C. Chambers*

*Sports Studies and Physical Education, School of Education, University College Cork, Ireland.

Summary: Clearly, physical literacy is a broad concept. Whilst the original term had strong philosophical orientations towards the concepts of phenomenology and existentialism, recent developments of the concept have largely focused on a more pragmatic interpretation in physical education, physical activity and sport; it appears that the application of the concept of physical literacy has led to a focus on learning more rudimentary skills. This has moved physical literacy away from its original and more holistic focus, intended by Whitehead (2007; 2013). The design challenge, therefore, is how to reimagine the pedagogy of physical literacy such that it remains relevant to its holistic origins. This is a complex problem to which we applied a human-centred innovation process called design thinking at a recent AIESEP workshop (with 92 stakeholders from 17 countries). In the workshop, teams innovated four new prototypes (solutions) in response to the problem statement. Across these prototypes, five core aspects of effective physical literacy pedagogy were identified using thematic analysis: (1) a life-long and life-wide focus; (2) Interdisciplinary design teams are needed to design and implement it; (3) the need for hybrid pedagogies i.e., both faceto-face and virtual; (4) space (virtual and physical) as an enabler; (5) how to nurture the symbiotic relationship between physical literacy and physical education. Further to this the $D^{3}$ Prism of Innovation Praxis (Chambers \& Sammon, in press) provided a sophisticated framework for this design challenge. It is intended to develop an overarching (prototype) solution which embraces these five aspects at a follow-on AIESEP workshop in 2021. Keywords: design thinking mindset; process; space; education; wicked problems. 


\section{eJRIEPS Hors Série 4 Juillet 2021}

Repenser les pédagogies de la littératie physique: utilisation du design thinking en tant qu'approche d'innovation

Résumé : De toute évidence, la littératie physique est un concept large. Le terme original présentait de fortes orientations philosophiques centrées sur les concepts de phénoménologie et d'existentialisme. Les développements récents du concept se sont largement concentrés sur une interprétation plus pragmatique de l'éducation physique, de l'activité physique et du sport. Il semble ainsi que l'application du concept de littératie physique s'est progressivement centrée sur l'apprentissage d'habiletés plus fondamentales. Cela a éloigné la littératie physique de son objectif original et plus holistique, voulu par Whitehead (2007; 2013). Par conséquent, le défi que présente la littératie physique consiste à savoir comment réinventer la pédagogie de sorte qu'elle reste pertinente par rapport à ses origines holistiques. II s'agit d'un problème complexe auquel, lors d'un récent séminaire de I'AIESEP (avec 92 acteurs-clés issus de 17 pays), nous avons appliqué un processus d'innovation centré sur l'humain appelé 'design thinking'. Au cours du séminaire, répartis en groupes, les participants ont imaginé quatre nouveaux prototypes (solutions) en réponse à l'énoncé $d u$ problème. À travers ces prototypes, cinq aspects fondamentaux d'une pédagogie efficace de la littératie physique ont été identifiés à l'aide d'une analyse thématique: (1) une priorité portée sur l'ensemble de la vie et tous les domaines de la vie; (2) la nécessité d'équipes de réflexion interdisciplinaires pour la concevoir et la mettre en œuvre; (3) le besoin de pédagogies hybrides, c'est-à-dire à la fois en face à face et virtuelles; (4) l'espace (virtuel et physique) en tant que catalyseur; (5) le comment entretenir la relation symbiotique entre la littératie physique et l'éducation physique. Par la suite, le Prisme de la Pratique d'Innovation $D^{3}$ (Chambers \& Sammon, sous presse) a fourni un cadre de référence pour ce défi de conception. Sur cette base, lors d'un séminaire de suivi organisé en 2021 par l'AIESEP, il est prévu de développer une solution globale (prototype) qui englobera ces cinq aspects.

Mots-clés : conception du design thinking ; processus ; espace ; formation ; problèmes pernicieux. 


\section{eJRIEPS Hors Série 4 Juillet 2021}

\section{Introduction: The Design Challenge}

On 25th February 2020, the Association Internationale des Écoles Superièure d'Éducation Physique1 (AIESEP) hosted a Specialist Symposium. Those who attended had answered the following AIESEP call:

Clearly, physical literacy is a broad concept. Whilst the original term had strong philosophical orientations towards the concepts of phenomenology and existentialism, recent developments of the concept have largely focused on a more pragmatic interpretation. From our vast experience educating professionals in the area of physical literacy in physical education, physical activity and sport, it appears that the application of the concept of physical literacy has led to a focus on more rudimentary skills which has moved physical literacy away from its original and more holistic focus intended by Whitehead $(2007 ; 2010)$.

AIESEP now wonder if it might be timely to pause and reflect on the nature and purpose of current interpretations of physical literacy and to examine how other newer and related ideas might provide an understanding of the complex interplay between the individual and his/her ecological environment in the physical education, sport and physical activity contexts.

This AIESEP Design Thinking workshop is an opportunity to engage in a 'design sprint' to innovate and iterate new pedagogies to promote physical literacy in the $21 \mathrm{st}$ century PE, sport and physical activity contexts. We invite all those who have a vested interest in promoting physical literacy amongst children and young people to join us in this unique workshop setting.

This symposium follows on from our Physical Literacy roundtable in AIESEP 2019 (Adelphi University, Garden City, New York) ... giving us the opportunity to continue this important conversation (AIESEP, 2019).

Our broad design challenge was 'to redesign pedagogies of physical literacy' - an educational challenge which is intergenerational, multi-sectoral and multi-cultural. For the purposes of clarity the definition of physical literacy is based on an adaptation of the United

\footnotetext{
${ }_{1}^{1}$ AIESEP is an international professional association which develops, disseminates and promotes high quality research and praxis in PE, physical activity and school sport.
} 


\section{eJRIEPS Hors Série 4 Juillet 2021}

Nations Educational, Scientific and Cultural Organization's definition of "literacy," "physical literacy", defined as:

The ability to move with confidence and competence using all the physical assets one has at their disposal at any given point in time across varying contexts. It involves a continuum of learning by enabling individuals to achieve their goals; to develop their knowledge, movement, and potential; and to participate fully in their community and wider society (Dudley, Cairney, Wainright, Kriellaars \& Mitchell, 2017, p.6).

The term pedagogy is defined as the art and science of learning and teaching. It has been noted that the term physical literacy is a 'hot topic' and has had multiple interpretations depending on professional culture and context (Chambers, 2020) For this reason the pedagogy of physical literacy is termed a wicked problem. Rittel and Webber (1973) described such problems as 'wicked' as they lacked both definitive formulations and solutions and were characterised by conditions of high uncertainty and in Blackman et al.'s (2006) words 'no single solution applies in all circumstances' (p.70). Therefore, Buchanan (1992) concluded linear analytical approaches were unlikely to successfully resolve them. According to Peters (2017, p.288), wicked problems have nine particular characteristics:

1. They are difficult to define;

2. They have no definite formation;

3. There is no stopping rule;

4. The solutions to wicked problems are good or bad, but not true or false;

5. There is no immediate or ultimate test for solutions;

6. All attempts for solutions come with a warning i.e. they may not be reversible or forgettable;

7. They have no clear solution or set of solutions; each wicked problem is unique;

8. A wicked problem may be a symptom of another problem; and

9. There are multiple explanations for a wicked problem.

It was clear that we needed an innovative approach which could handle this level of complexity (wickedness); an experimental approach which explores multiple possible solutions. More than this, it required a process that could provide space for stakeholders to become active players in tackling this design challenge: to redesign pedagogies of physical literacy. Design thinking appeared to be such an innovative approach. 


\section{What is design thinking?}

Design is the third area of human knowledge that fuses with humanities and science (Archer, 1979), a powerful interconnected triad. 'Design is ambiguous by nature - in fact ambiguity is the heartbeat of design' (Chambers, 2020, p.43). To help tackle this design challenge redesigning the pedagogy of physical literacy - we turned to a particular genre of design i.e., design thinking (Brown, 2008). According to Liedtka (2015) the defining pillars of design thinking are problem centeredness, nonlinearity, optionality, and the presence of uncertainty and ambiguity. Design thinking is universally used in innovation to solve intractable human-centred problems (Buchanan, 1992). In so doing, it engages creative multi-disciplinary, multi-stakeholder teams to use a systematic and collaborative approach to identifying and creatively solving problems (Luchs, Swann \& Griffin, 2016, p. 2). Design thinking brings 'designers' principles, approaches, methods, and tools to problem solving' (Brown, 2008, p.1). Lockwood (2016) asserts that the design thinking process 'emphasises observation, collaboration, fast learning, visualization of ideas, rapid concept prototyping, and concurrent business analysis' (n.p.). The design challenge redesigning the pedagogy of physical literacy was wicked (complex) as it is 'not stable but continually evolving and mutating and had many causal levels' (Blackman et al., 2006, p.70) and adding to this complexity, there are intergenerational, multisectoral and multicultural stakeholders with a range of philosophical views.

The ultimate solutions to wicked problems are located at the sweet spot (i.e., design innovation) (IDEO, 2009) (Figure 1). The sweet spot is the intersection of three aspects: (1) what is desirable from a human point of view (using design thinking) with (2) what is technologically feasible (agile development) and (3) what is economically viable (lean thinking) (Brown, 2016). Design thinking attends to the desirability aspect of the solution and is the first comprehensive process. Once a solution has been identified through design thinking, designers look to feasibility using agile learning methods and then, viability of the solution using lean thinking. Lean thinking is a business methodology that aims to provide a new way to think about how to organize human activities to deliver more benefits to society and value to individuals while eliminating waste (Womack \& Jones, 2003). One key element of lean thinking is flow. Flow in this context is a description of how people engage in the process from the beginning to the end. It involves continuous improvement which means 


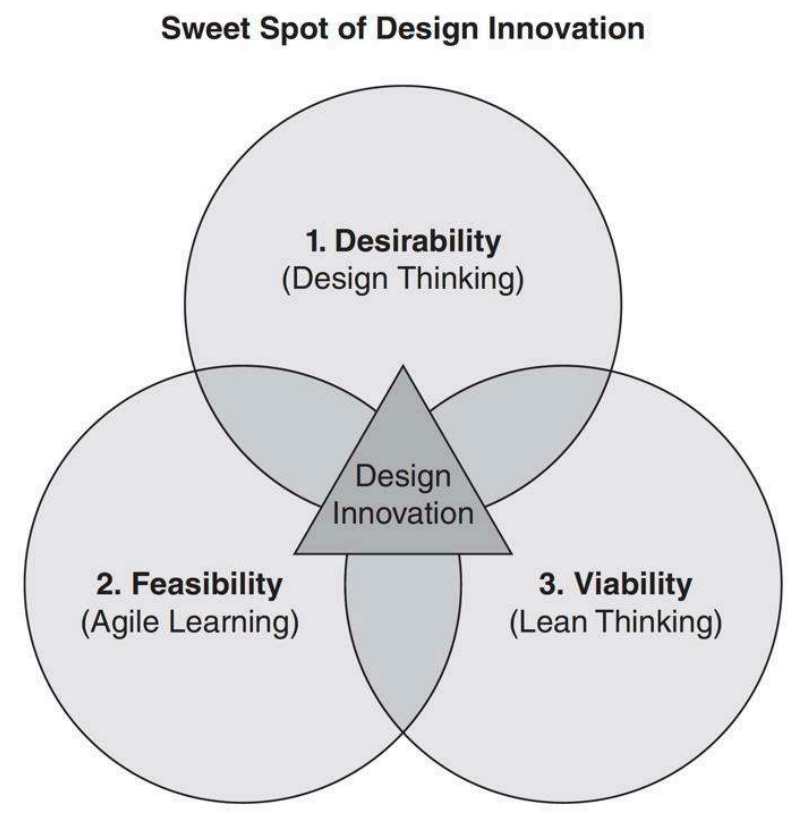

Figure 1. Sweetspot of Design Innovation (Chambers, 2020 adapted from IDEO, 2009)

iteration and evolution of ideas and processes. Agile learning (Longmuß, Höhne, Bräutigam, Oberländer \& Schindler, 2016) is then employed to ensure that the solution can be scaled or delivered continuously. It is 'based on the principles of inquiry based learning on the part of the learner and a demand driven, empowering perspective of the learning coaches ("Give what is needed when it is needed")' Longmuß et al., 2016 p.3). To begin, we used design thinking to grapple with our design challenge. There are three enabling factors for any design team (Figure 2) design thinking process, design thinking mindset and design thinking space. Each of these elements will be described in detail in the forthcoming sections.

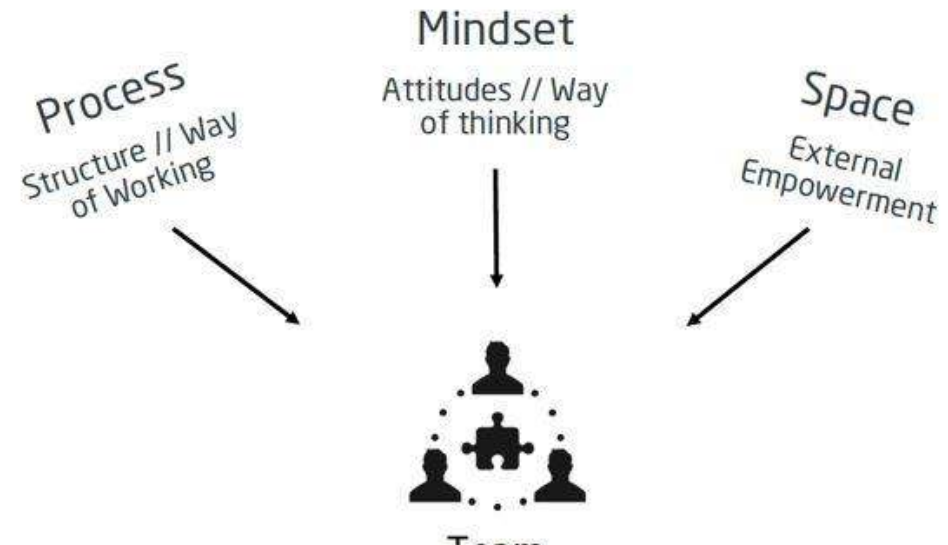

Figure 2. Enabling Factors for the Design Team (Hasso Plattner Institute, 2019) 


\section{eJRIEPS Hors Série 4 Juillet 2021}

\section{The Design Thinking Process}

The process of design thinking itself is a multi-stage iterative process that has been outlined by many different theorists (Table 1). There are three agreed design thinking spaces Inspiration, Ideation and Implementation (Brown, 2008). Design thinkers move iteratively between these spaces to make sense of the problem, to ideate solutions and then to test these solutions (Borja de Mozota \& Peinado, 2013). Put more succinctly, Inspiration is the problem or opportunity that motivates the search for solutions; Ideation is the process of generating, developing, and testing ideas; and Implementation is the path that leads from the project stage into people's lives (Table 1). Theorists agree that all design thinking begins with compassion or empathy. This refers to a desire to truly understand the stakeholders for whom the problem pertains. Once this has been ascertained, the designers move into ideation to brainstorm solutions which can be tested in implementation phase. Regardless of the model, there is always to broad spaces i.e., Problem Space- Solution Space. Note in the case study workshop described here, we used the Hasso Plattner Institute six-stage model (Table 1).

The Design Council (2005) developed a double diamond, a divergence-convergence model to showcase the Problem-Solution spaces more clearly. While they use different language (the four stages Discover, Define, Develop and Deliver), they argue for a particular way of conducting design whatever the model i.e.: (1) put people first; (2) communicate visually and inclusively, (3) collaborate and co-create and (4) iterate, iterate, iterate. During this iterative process, $80 \%$ of the design time is spent working in the problem space (or Inspiration Space) and $20 \%$ of the time working in the solution space (Ideation and Implementation). The Design Council (2019) have recently presented an 'evolved double diamond'. This includes engagement and leadership as core to a sustainable design thinking approach. This more 
Table I. Eight Models of Design Thinking (Chambers, 2020, p.45)

\begin{tabular}{|c|c|c|c|c|c|c|}
\hline \multirow{3}{*}{$\begin{array}{l}\text { Design thinking models } \\
\text { The IDEO Model } \\
\text { (IDEO, 2009) }\end{array}$} & \multicolumn{6}{|c|}{ Design thinking spaces (IDEO, 2009) } \\
\hline & Inspiration & & & Ideation & & Implementation \\
\hline & Discovery & & Interpretation & Ideation & Experimentation & Evolution \\
\hline $\begin{array}{l}\text { The d.school model } \\
\text { (d.school Stanford, 2010) }\end{array}$ & Empathise & & Define & Ideate & Prototype & Test \\
\hline $\begin{array}{l}\text { Design Thinking and Innovation Model } \\
\text { (Goligorsky, 2012) }\end{array}$ & Clarification & & & Ideation & Development & Implementation \\
\hline $\begin{array}{l}\text { Designing for Growth } \\
\text { Model (Liedtka 2015) }\end{array}$ & What is? & & & What if? & What wows? & What works? \\
\hline $\begin{array}{l}\text { Six Stage Model } \\
\text { (Hasso-Plattner Institute, 2018) }\end{array}$ & Understand & Observe & Point of view & Ideate & Prototype & Test \\
\hline $\begin{array}{l}\text { Figure of } 8 \\
\text { (Sammon, 2016) }\end{array}$ & Exploring & Understanding & Defining & Designing & Building & Evaluating \\
\hline $\begin{array}{l}\text { A Framework of Design } \\
\text { Thinking } \\
\text { (Luchs, Swan, \& Griffin, 2016) }\end{array}$ & Discover & & & Define & Create & Evaluate \\
\hline $\begin{array}{l}\text { The Chambers' 4-Stage Model } \\
\text { (Chambers, 2018) }\end{array}$ & Compassion & & & Ideate & Prototype & $\begin{array}{l}\text { Implement and } \\
\text { evaluate }\end{array}$ \\
\hline
\end{tabular}

ecological view of design acknowledges what is needed to build a design environment that supports capability building and long-term impact. In so doing, it is important to call out the need for an ethical approach to design, whether the focus is on product, process or service. Smirnow's (2017) features of service design are very helpful here: (1) A strategic and systems approach that visualizes and addresses complex issues with a holistic view; (2) Human-centred research driven by design ethics with high levels of empathy; (3) Value exchange and gain for all stakeholders through shared information flows; (4) Situational, interaction-based learning facilitated by design tools and mutual reflection. Building on this, Smirnow (2017) calls out six design thinking principles which speak directly to the work of the Design Council in encouraging a more sustainable approach to the design process itself:

Design for Transition: To create engaging, safe spaces to critically reframe assumptions, beliefs and understanding during times of change, growth and transition, helping to overcome barriers that result from pre-established and deeply ingrained social roles, boundaries and hierarchies.

Accessible Mutable System: Not only the activities (but the system itself) should be accessible, open sourced and 'hackable' to tailor experiences to different contexts and levels of understanding/engagement.

Mutual Learning through Exploration: Teachers, staff and students engage simultaneously in learning to generate data with values beyond the individual social context within the University (or in other jurisdictions)

Facilitated Learning About Oneself and Others: Moments that enable and encourage 'deeper learning' for all participants. A variety of resources offered (and a clear 'game plan') allow for self-directed reflection.

Multiple Levels of Intimacy: The scale of reflection on both levels, individual and group, plays an important role in building trust and processing the key takeaways about research contingencies. 


\section{eJRIEPS Hors Série 4 Juillet 2021}

At Your Discretion: Openness and mutual learning are encouraged but, the disclosure of sensitive information happens only according to the comfort level of each individual.

These features and principles are the markers of a design thinking pedagogy which nurtures the (1) design thinking mindset, (2) design thinking process and empowers us to use space differently when engaged in innovative praxis i.e. (3) the design thinking space.

\section{The Design Thinking Mindset}

As stated earlier, the process of design thinking involves the "development of idea stages, applying an iterative process that forces solvers to move back and forth between inspiration, ideation and implementation" (Borja de Mozota \& Peinado, 2013, p.1). Carlgren, Elmquist and Rauth (2016) put design thinking on three levels: (1) principles and practices, (2) mindsets and (3) techniques. Di Russo (2016) concludes that 'most definitions present design thinking as a mindset, method, process, attitude or a combination of all four' (p. 259). Hassi and Laakso (2011) identify it as a form of practices, cognitive approach and mindset (Figure 3).

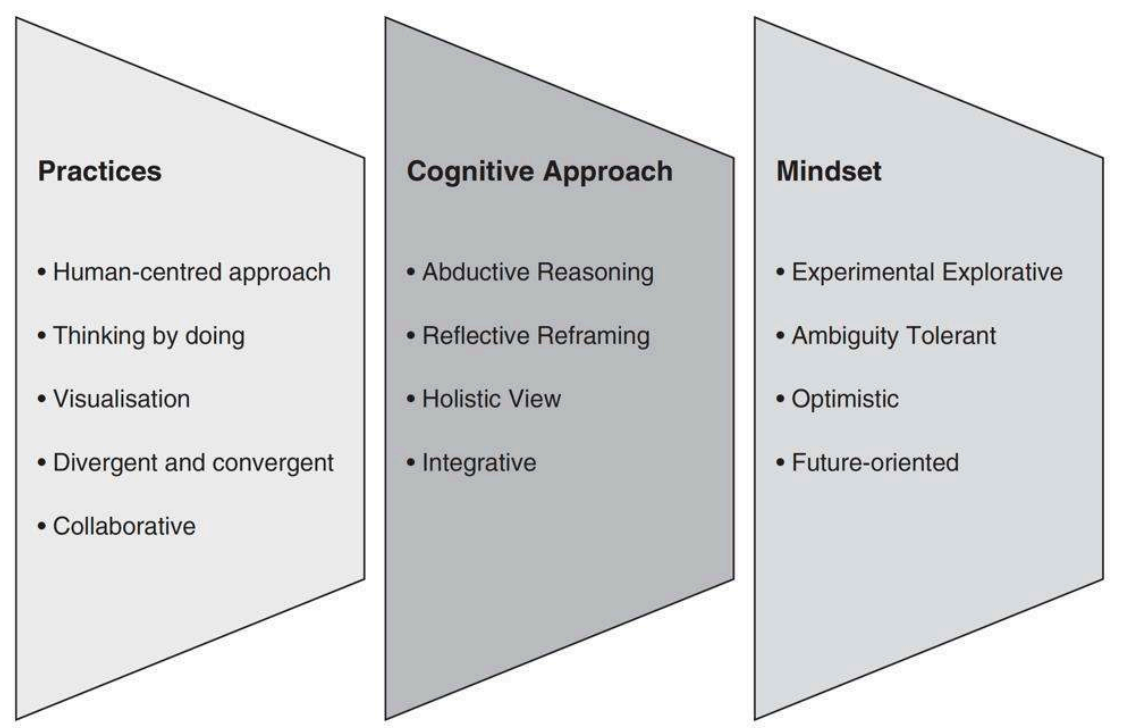

Figure 3. Mindset of a Design Thinker (adapted from Hassi \& Laakso (2011) by Chambers, 2018)

Going deeper into the mindset component, Schweitzer, Groeger and Sobel (2016) identified eleven design thinking mindsets based on interviews with expert design thinking practitioners:

1. having empathy towards people's needs and context, 


\section{eJRIEPS Hors Série 4 Juillet 2021}

2. embracing collaboration and diversity,

3. being inquisitive and open to new perspectives and learning,

4. being mindful of process and thinking modes,

5. embracing experiential intelligence,

6. taking action deliberately and overtly,

7. being consciously creative,

8. accepting uncertainty and being open to risk,

9. modelling behaviour,

10. having the desire and determination to make a difference, and

11 . being critically questioning.

From this, it is clear that design thinkers are therefore comfortable with uncertainty and ambiguity. This is a key threshold concept in design (Meyer \& Land, 2003) as it is both transformative and irreversible i.e. once known, it cannot be unknown. This disposition allows the design thinker to "infer possible new worlds" (Martin, 2009, p.65) or opportunities. Moreover, the cognitive approach embraces abductive reasoning. Shearer (2015) asserts that when using abductive reasoning, there is a need to understand how different kinds of conjectures might interact with one another during this part of the design development. The dictionary definition of conjecture asserts that this is a form an opinion or supposition about (something) on the basis of incomplete information. By doing this, it helps provide a way to help multi-disciplinary design teams collaborate. This helps to mitigate against false representations of reality.

On an individual/personal level, Windahl (2017, p.280) asserts the importance of curiosity, creativity and courage when desirability, rather than feasibility or viability, is the locus of innovation activities. She asserts that (1) curiosity ignites empathy and deep understanding of the human experience; (2) creativity awakens 'logical leaps' in understanding opportunities; and (3) courage enflames learning through iterations, which reduces cognitive bias. Curiosity has four dimensions (Merck, 2018) (Figure 4). These are openness to people's ideas; joyous exploration; stress tolerance and deprivation sensitivity. 
Openness to People's Ideas Valuing people with diverse perspectives and ideas and intentionally seeking out different approaches

\section{Joyous Exploration}

The pleasure of recognising and seeking out new knowledge and information and the subsequent joy of learning and growing

\section{Stress Tolerance}

The willingness to embrace the doubt, confusion, anxiety, and other forms of distress that arise from exploring the new and uncertain

\section{Deprivation Sensitivity}

Recognising a gap in

knowledge and pondering abstract or complex ideas to try to solve the problem or reduce the gap

Figure 4. Dimensions of Curiosity (adapted from Merck, 2018)

According to Chambers (2020, p. 48):

it is this rounded view of curiosity helps to explain how curious people react with open, non-defensive attitudes and effortful thinking. Such a disposition can be of benefit in an ever-changing and unpredictable environment, as individuals are less likely to perceive change as stressful and more likely to adapt effectively. When partnered with creativity and courage, it becomes even more potent as it unleashes the design for impact.

This could be termed as a growth mindset (Dweck, 2012) wherein the design thinker perceives his/her ability not as fixed but flexible, and as something that can be developed through effort.

Groeger, Schweitzer, Sobel and Malcom (2019 (pp 2-3) purport that it is the design thinking mindset that enables innovation objectives to be achieved at a deeper and more sustainable level. The cookie-cutter, template driven model of design thinking achieves a more surface level of change. Nussbaum (2011) reported how some are so fixated on process that design thinking is turned into a rigid plan, which is implemented like any other efficiency-based process (Nussbaum, 2011). The design thinking mindset is the secret sauce which ensures that the process is not driven by templates. It leads to a more sustainable solution. For designers, the space in which design thinking happens is really important. In fact, design is seen as an embodied practice in space. 


\section{eJRIEPS Hors Série 4 Juillet 2021}

\section{The Design Thinking Space}

The physical environment that we construct is as much a social phenomenon as it is a physical one (Proshansky, Ittelson \& Rivlin, 1970). In fact, when generating ideas, it becomes really important to be very fluid and have the ability to move in and out of different concepts and different people's voices as an idea is coming to fruition. Therefore, creating a space that allows movement and encourages an active posture really helps collaboration to move more smoothly, and can push creativity by allowing people to participate when they want, step out when they do not, and permit leadership to move throughout the group (Doorley \& Witthoft, 2011). It affords designer autonomy as ideas bounce off people and the space in which they work. For this to happen, Lawson (2001, p.8), asserts that we often need to tell space how to behave, so that it serves our purpose. Norman (2002) describes how we do this by outlining space typologies - A space type being a dedicated space for a particular activity at a specific time. He outlines how space has an inherent affordance, in other words it is an enabler for the particular activity taking place in that space. Every time the configuration changes, so, too, does the space type. The more flexible the space - the easier the transition. According to Thoring, Desmet \& Badke-Schaub (2018), there are five types of creative spaces:

(1) The personal space, for working and learning alone; (2) the collaboration space for working or learning together with co-workers, classmates or teachers; (3) the presentation space, for giving presentations, consuming lectures and displaying or examining creative work examples; and (4) the making space in which people are able to experiment, try things out, build stuff and make noise and (5) the intermission space for transition and recreation. The latter includes spaces not intended for creative design work but connect other space types: hallways, cafeterias, the outdoors - and provide spaces for breaks (my emphasis, p.64)

Thoring et al. (2018) have also added another qualitative aspect to this typology and that is 'space quality'. This is linked to Norman's notion of affordance - and is more nuanced. It measures the ability of a space to facilitate a specific purpose, independent from the space type. In their words, they highlight five qualities of a creative space: (1) space as a knowledge processor; (2) space as an indicator of culture; (3) space as a process enabler; (4) space as a social dimension; (5) space as a source of stimulation. 


\section{eJRIEPS Hors Série 4 Juillet 2021}

It is important to understand how the process, mindset and space in design thinking work together. Therefore in the next section we look to The $D^{3}$ Prism of Innovation Praxis (Chambers \& Sammon, 2020).

\section{The $D^{3}$ Prism of Innovation Praxis}

In order to design an impactful solution, we need to embrace The $D^{3}$ Prism of Innovation Praxis was coined by Chambers \& Sammon (in press). It explains the pedagogy and praxis of design thinking across the three core pillars: (1) design thinking process, (2) design thinking mindset and (3) design thinking space. It comprises three core fluencies: design fluency, digital fluency and data fluency. It is helpful in drawing attention to the potency of these three fluencies in driving innovation for impact. Sparrow's (2018, p.54) work is helpful here in defining fluencies. Chambers and Sammon (in press) have augmented this work, representing within their $\mathrm{D}^{3}$ Prism:

1. Design fluency (presented here as a combination of Sparrow's (2018, p.54) creation fluency, curiosity fluency and innovation fluency). Innovation fluency includes the realization that failure is a valuable part of the learning process. To innovate, students need to take risks, fail, learn from those failures, and iterate the process to bring a new idea to fruition. For many years, educators have utilized metacognition in the learning process: learning how someone learns and reflecting on that learning are key to applying what was learned to new situations. Creation fluency, or maker fluency, is a deep understanding of how to create and leverage knowledge to make something new. These creations can by physical or virtual and can include 3D printing and programming. Curiosity fluency involves having questions and a desire to answer those questions. It prepares students not to just Google an answer but to be aware they are capable of developing their own answers to questions. Opportunities for developing curiosity fluency include providing students with practice and deep immersion in design thinking throughout their education and with an unbound, rulesfree environment to think differently about the challenges we face in the $21^{\text {st }}$ century.

2. Digital fluency (with Sparrow's (2018, p.54) Communication fluency). This is 'the ability to leverage technology to create new knowledge, new challenges, and new problems and to complement these with critical thinking, complex problem solving, and social intelligence to solve the new challenges. Digital fluency also requires excellent communication skills, new media literacy, and cognitive load management 


\section{eJRIEPS Hors Série 4 Juillet 2021}

to address the issues, and concerns we face today and in the future. It includes: Communication fluency, which is the ability to communicate new knowledge across diverse populations and to choose a medium that is appropriate and most impactful for a given audience. Digital storytelling is one means of communicating new research findings. Additionally, students can use virtual reality and augmented reality. Using VR or AR to tell a story, learners need to understand not only how the technology works but also the impact on the reader and the fact that this medium can change how a story might be told.

3. Data fluency. This is the capacity to use data sets to make informed decisions, along with the knowledge to push the boundaries of what the technology can do to process the data to ask new questions. If learners have access to cloud computing resources, data science knowledge, and big data sets, the types of questions they will ask will be bound only by their imaginations (Sparrow, 2018, p.54).

$D^{3}$ Prism for Innovation Praxis provides a pedagogical handrail for educators, which helps them to prepare our students for the $85 \%$ of jobs that will be available in 2030 that haven't been invented yet (Dell, 2017).

In the next section, the design thinking workshop at the heart of this article is presented. This provides an opportunity to amplify the design thinking process, mindset and use of space and more particularly to highlight the fluencies at play during this very dynamic workshop.

\section{Case Study}

The design challenge was 'to redesign pedagogies of physical literacy' - an educational challenge which is intergenerational, multi-sectoral and multi-cultural. In this AIESEP symposium, the design thinking workshop format encouraged participants to work together through a number of phases to 'redesign the pedagogy of physical literacy'. The spirit of the workshop was one of dynamism. It was fast-paced and relied on participants embracing a growth mindset, interacting with the space and following the Hasso-Plattner Institute (2018) six-stage design thinking process (Table I and Figure 5). 
eJRIEPS Hors Série 4 Juillet 2021

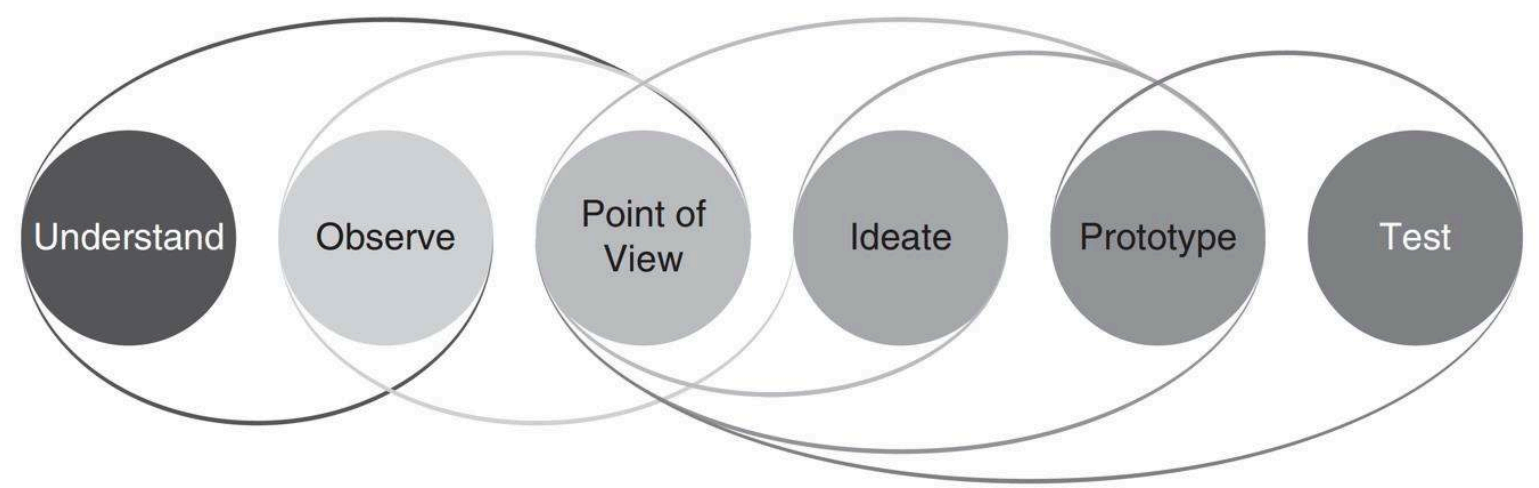

Figure 5. Six-Stage Design Thinking Process (Hass Plattner Institute, 2018)

\subsection{Participants}

There were 92 participants who self-selected to experience the symposium. They comprised: curriculum developers, Physical Education teachers, Physical Education Teacher Education faculty, academics, sports coaches, politicians, etc. They were drawn from 17 countries: Belgium, Canada, China, The Netherlands, England, Finland, France, Germany, Ireland, Italy, Japan, Luxembourg, Northern Ireland, Poland, Switzerland, Taiwan, and Wales. The participants had little to no experience of design thinking, but were experts in PE, PA and/or sport and in particular physical literacy. Participants were divided into Master-Teams A, B, C or D. These master-teams were then subdivided into four further subteams e.g., Master-Team A became sub-team A1, sub-team A2, sub-team A3, sub-team A4. Each team had an English-speaking leader. Master-Team and sub-team lists were on the walls outside the room. Participants were greeted by one facilitator to ensure that all located their sub-team space quickly.

\subsection{Design Ethics}

When working on a design challenge, it is important to remember those who will be most impacted by the solution i.e., the end-user. The design thinking coach and/or facilitator must attend to design ethics as this is a human-centred innovation. As such, particularly in relation to service design, design thinking is able to humanise and visualise complex systems through research and scenarios. It can create new relations and interactions between the main actors and can lead to new knowledge. In order to facilitate this, the design thinking coach and/or facilitator must behave in an ethical manner by being authentic; bringing awareness; knowledgeable about the subject matter; makes no assumptions, values every collaborator as an expert of their own lives, presents a willingness to learn and be respectful; and to be mindful of confidentiality of every conversation and how it informs the design 


\section{eJRIEPS Hors Série 4 Juillet 2021}

proposal (adapted from Smirnow, 2017, p.40). These are crystallised in Smirnow's (2017) six design principles. The workshop used these to inform the pedagogy of design thinking (Table II).

Table II. Design Principles and Pedagogy of Design Thinking (adapted from Smirnow, 2017)

\begin{tabular}{|l|l|}
\hline Design Principles & Pedagogy of Design Thinking \\
\hline Design for Transition & $\begin{array}{l}\text { The creation of multi-stakeholder teams } \\
\text { Establishment of clear rules of engagement }\end{array}$ \\
\hline Accessible Mutable System & $\begin{array}{l}\text { An agile workshop agenda } \\
\text { All activities were chosen to allow for maximum engagement } \\
\text { Timeboxing helped participants to stay on task }\end{array}$ \\
\hline Mutual Learning through Exploration & Mixed stakeholder teams and an identified leader \\
\hline Facilitated Learning About Oneself & Reflective exercises \\
\hline Multiple Levels of Intimacy & Group reflection at each stage \\
\hline At Your Discretion & $\begin{array}{l}\text { Participants were advised that sharing of personal information } \\
\text { was at their own discretion }\end{array}$ \\
\hline
\end{tabular}

\subsection{Use of Space}

Interestingly, the workshop space for the AIESEP design thinking workshop exhibited three creative space types: collaboration space; presentation space; and making space. The workshop space, both collaboration and presentation space (Thoring et al., 2018) was a large bright room with movable furniture. Furthermore, it exhibited three of Norman's (2002) five qualities of a creative space - it enabled knowledge processing, it was a process enabler and the space had a social dimension. It was organized into four zones according to the master-teams (A, B, C, D) with four tables per zone for the sub-teams (A1-A4; B1-B4; C1C4; D1-D4). Each table had an allocated wall or window space for their work. Every subteam was allocated markers, sticky notes, blue tack and A2 sheets of paper. The intermission space (Thoring et al., 2018) was a bright room for drinks, snacks and lunch.

\subsection{Design Thinking Process}

In this seminar, we used a six-step design process (Figure 4) which was developed by the Hasso Plattner Institute. The steps fall into Problem Space (Compassion) and Solution Space. As stated earlier, it is important to spend as much time as possible in the problem space $-80 \%$ and then the remaining time in the solution space. The design thinking 


\section{eJRIEPS Hors Série 4 Juillet 2021}

pedagogy enables this to happen. The process began with Compassion - namely, empathising with the case study (persona) and being inclined toward action (Figure 3 for an example persona).

There are three sub-phases in the compassion space - understand, observe and point of view (or synthesise) as outlined by Chambers (2018). Empathy is 'I understand how you feel', whereas compassion is, I understand how you feel and am driven to do something that has a positive impact on you. This involves trying to really understand the case at hand and to settle on a point of view or synthesis of the issue at the heart of the case. For the purposes of starting to imbue compassion in participants, it begins with focusing on the end-user in physical education and physical literacy - a composite case called John (Figure 6). Participants are urged to think about John throughout the workshop and how what they will design will impact on how we support John on his physical literacy journey in the context of physical education.

There were four design thinking challenges which were informed by the (1) original broader problem statement and (2) the Megatrends in Education (OECD, 2019). Each design challenge was assigned to a Master-team:

Master-Team A. Redesign online and offline pedagogies for children in a world where there is limited funding.

Master-Team B. Redesign pedagogies for physical literacy for children in a world where sustainability is a core value.

Master-Team C. Redesign learning spaces and pedagogies to promote risky play in a world which is uber safety conscious.

Master-Team $D$. Redesign a factfulness approach to physical literacy in a world where pupils live in an echo chamber.
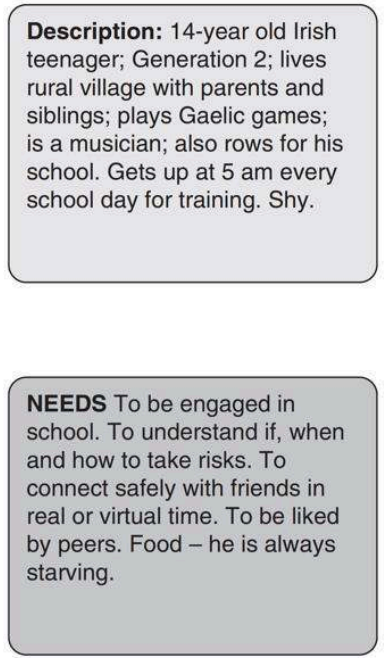

Thinks training is BORING as they do the SAME thing every session. Gets frustrated when coach can't answer his questions and often goes on-line to find things out. Trying to bulk up using creatine supplements Got them from a friend in the rowing club.

John

Figure 6. Sample Persona (John)

INSIGHT: Unsure of himself, his appearance, his opinions, his masculinity. Relies on YouTube videos for health and training information. Did not tell his parents about the creatine supplements he is taking. 


\section{eJRIEPS Hors Série 4 Juillet 2021}

The agenda for the day was agile, with process tasks designed for each iterative phase of the design thinking process, which would encourage curiosity, creativity and courage (Windahl, 2017).

\subsection{Prototypes (Results)}

In Table III, the design challenge and the resultant prototype are shown for each of the four master-teams.

Table III. The Workshop Point of View Design Challenges (using the Hasso Plattner Institute Six Step Model, 2018)

\begin{tabular}{|c|c|c|}
\hline $\begin{array}{c}\text { Master- } \\
\text { Team }\end{array}$ & Design Challenge & Prototype \\
\hline A & $\begin{array}{l}\text { Redesign online and offline } \\
\text { pedagogies for children in } \\
\text { a world where there is } \\
\text { limited funding. }\end{array}$ & $\begin{array}{l}\text { Cre@tive journey: lifelong and lifewide physical literacy } \\
\text { An ecological model with both a life-long and life-wide physical } \\
\text { literacy model. This includes schools, employers etc. }\end{array}$ \\
\hline B & $\begin{array}{l}\text { Redesign pedagogies for } \\
\text { physical literacy for } \\
\text { children in a world where } \\
\text { sustainability is a core } \\
\text { value. }\end{array}$ & $\begin{array}{l}\text { Interdisciplinary design teams for physical literacy: physical } \\
\text { literacy needs to be designed, implemented and evaluated by } \\
\text { interdisciplinary teams e.g. pediatricians, urban designers, } \\
\text { physical education teachers, employers, medical doctors, } \\
\text { school staff, architects, politicians. }\end{array}$ \\
\hline C & $\begin{array}{l}\text { Redesign learning spaces } \\
\text { and pedagogies to } \\
\text { promote risky play in a } \\
\text { world which is uber safety } \\
\text { conscious. }\end{array}$ & $\begin{array}{l}\text { Space as an enabler for physical literacy. Redesign school to } \\
\text { promote risky play. Pedagogical scenarios/stories to help } \\
\text { children to learn risky play and to translate it from physical } \\
\text { education class to playground to home. }\end{array}$ \\
\hline D & $\begin{array}{l}\text { Redesign a factfulness } \\
\text { approach to physical } \\
\text { literacy in a world where } \\
\text { pupils live in an echo } \\
\text { chamber. }\end{array}$ & $\begin{array}{l}\text { Learning how physical literacy is informed by physical } \\
\text { education and by broader education goals: Gamification } \\
\text { (Fortlife): There is a need for a clear physical literacy } \\
\text { framework which can easily articulate its focus and how it links } \\
\text { to physical education; it is clear that physical literacy fits with } \\
\text { global goals of education. It is possible to capture children's } \\
\text { attention by using gaming e.g. Fortlife - Are you ready to save } \\
\text { your life? }\end{array}$ \\
\hline
\end{tabular}

All four prototypes were thematically analysed using Voyant, a data analysis coding tool. During the data analysis process, five key themes were identified as core to effective physical literacy pedagogy. They are:

1. Life-long and life-wide physical literacy;

2. Interdisciplinary design teams are needed to innovate, implement and evaluate physical literacy pedagogy;

3. Hybrid delivery required i.e. both face-to-face and virtual;

4. The importance of space as an enabler for quality physical literacy pedagogy; and 


\section{eJRIEPS Hors Série 4 Juillet 2021}

5. The need to ensure that we map how physical literacy informs/and is informed by physical education i.e. the symbiosis of their relationship

In the discussion section, these themes will be further examined as they will provide a useful handrail when continuing to innovate a solution for the complex problem (reimagining a pedagogy of physical literacy).

\section{Discussion}

In using design thinking to solve such complex problem as the reimagining the pedagogy of physical literacy, it is important to acknowledge the iterative nature of the process. This workshop simply provided a one-day opportunity to begin this endeavour. To continue this important innovation journey, it is intended to innovate an overarching (prototype) solution which embraces these five aspects at a follow-on AIESEP workshop in 2021.

In defining their four prototypes, the teams provided a useful starting point for further iteration and testing. However, it is in fact the five features of effective physical literacy pedagogy that provide a north star in this next phase - These are powerful. We will now review each, presenting follow-on design nudges for consideration at the next workshop. Design nudges are considerations that might be made when iterating the solution prototype further toward the final Test phase of design thinking.

\section{Five Features of Effective Physical Literacy Pedagogy with Follow-on Design Nudges}

1. Life-long and life-wide physical literacy

Follow-on design nudges: Does this mean that physical literacy is something that can be learned and augmented throughout a lifetime? What implications does this have for physical education/sport/physical activity? In the context of life-wide, the implication is that many can help to empower physical literacy at particular points in the life journey - who are these stakeholders and how can this manifest itself?

2. Interdisciplinary design teams are needed to innovate, implement and evaluate physical literacy pedagogy

Follow-on design nudges: Consider who might be included or excluded from this group? On what basis are they chosen to be involved? How can you measure the impact of their insights?

3. Hybrid delivery required i.e., both face-to-face and virtual 


\section{eJRIEPS Hors Série 4 Juillet 2021}

Follow-on design nudges: How can this work in practice? What are the ethical considerations of such a move? How can a teacher/coach ensure an authentic learning experience for the person?

4. The importance of space as an enabler for quality physical literacy pedagogy Follow-on design nudges: When you think of space, is it both virtual and physical? How can virtual space be an enabler? Are their ethical considerations?

5. The need to ensure that we map how physical literacy informs/and is informed by physical education i.e., the symbiosis of their relationship

Follow-on design nudges: There seems to be confusion as to the place of physical literacy in the world of physical education? It would be helpful to tease this out with the design team and with end-users. During the process new and interesting insights may be uncovered which can help further the design solution.

As stated earlier in the paper, the design an impactful solution involves embracing The $D^{3}$ Prism of Innovation Praxis (Chambers \& Sammon, in press). A review of how teams engaged with this follows.

\section{$\mathrm{D}^{3}$ Prism of Innovation Praxis}

It was clear that teams did embrace the three fluencies to some extent. We will deal with these under the three facets of the prism:

Design Fluency. In the workshop, this was the most difficult element for teams. They struggled with being asked not to move to solution too quickly; to stay with the issue and interrogate that for a long period. In addition, it took some time to establish trust among team members. This impacted their ability to take risks when innovating. In addition, some team dynamics were difficult, which some more extrovert team members being very dominant in the discussions.

Digital Fluency. Some teams were very adept at this but it seemed to depend on the generations within that team and their familiarity with digital technology. The urge to use technology as a cure-all was tempered having a diverse group across multiple generations (McCrindle, 2019). This particular lens will be very important in the next phase of innovation in the 2021 workshop.

Data Fluency. As the teams were so diverse with a range of expertise, members did share their knowledge freely to interrogate the problem and then to build the prototype. It is clear that fluency can be further exploited at the next workshop using bigger data sets. 
The focus of this first workshop was fourfold: (1) to bring a diverse range of stakeholders together from a range of cultures and standpoints, all of whom have a vested interest in physical education, physical literacy and education more generally; (2) to teach the process of design thinking to the participants; (3) to create a safe and empowering design thinking space for the workshop and (4) to empower teams to innovate solutions to the design challenge using design thinking. It is clear that this has been achieved to an extent. This was evident from Dr Margaret Whitehead's comments in closing the workshop. Dr Whitehead, the theorist who proposed physical literacy addressed the group, commenting that it was the first time she had witnessed and been part of a cross-cultural, cross discipline design workshop which focused on the pedagogy of physical literacy. She supported the notion of creating a professional learning community which could develop from this event and who could develop pedagogies of physical literacy which could be applied in contexts around the globe. Participants were invited to take part in the follow-on seminar in AIESEP 2021 in Banff, Canada.

\section{Concluding remarks}

The case study showcases a unique moment in AIESEP history when 92 colleagues from 17 countries gathered to tackle a wicked problem for our profession over 6 hours. Reflecting on the impact of this experience, there are a number of key learnings which we will interrogate under three key headings (1) The $D^{3}$ Prism for Innovation Praxis; (2) Networks (3) Future directions.

1. The $D^{3}$ Prism for Innovation Praxis (Chambers \& Sammon, in press). It provides one lens through which this case study can be examined. It is evident that this powerful pedagogical handrail helps in planning, implementing and evaluating the impact of this design thinking case study. All 92 participants were novice design thinkers. They were presented with opportunities to develop design fluency through engagement in the design thinking tasks - They learned to take risks and to fail and to iterate. They also had opportunities to reflect on how they and other members of the team learned. Further to this, teams were encouraged to become 'makers' in order to visualise their ideas and to prototype their solutions. In addition, they showed a level of curiosity not only in relation to the problem but also in relation to what each team member might bring to the team. It is important to say that a one-day design thinking experience will 


\section{eJRIEPS Hors Série 4 Juillet 2021}

not develop fluency - it may simply awaken the learner to these possibilities. Speaking specifically about digital fluency, one team in particular was attentive to this acknowledging that many of their pupils were Generation Z or Generation Alpha (McCrindle, 2019). Teams used appropriate communication methods, but such skillsets could be deepened with greater immersive experiences in design thinking. The teams did not have an opportunity to engage in any meaningful way with data fluency. They were inhibited by the fact that this was a time-bound activity.

2. Networking opportunities. Many of the participants had never met before. The design thinking workshop provided a chance to work on a shared design challenge. It provided a chance for colleagues to build their professional networks and to debate important issues and to co-create a solution to the design challenge.

3. Future directions. It is clear that this was just be beginning of the design journey - As stated, it is intended that teams will meet again in AIESEP 2021 in Banff, Canada to continue prototyping, testing and iterating their solutions to the design challenge.

In conclusion, design thinking when presented as a component of the $\mathrm{D}^{3}$ Prism of Innovation Praxis is a powerful process, mindset and learning space. As we live in such uncertain times, our profession need to be design thinkers and to be comfortable with ambiguity, to embrace the innovation bubble and to reimagine and redesign physical education for the future.

\section{References}

Archer, B. (1979). Design as a discipline. Design Studies, 1(1), 17-20.

Blackman, T., Greene, A., Hunter, D.J., McKee, L., Elliott, E., Harrington, B., Marks, L., \& Williams, G. (2006). Performance assessment and wicked problems: the case of health inequalities. Public Policy and Administration, 21, 66 - 80.

\section{https://doi.org/10.1177/095207670602100206}

Borja de Mozota, B. \& Peinado, A. (2013). New Approaches to Theory and Research in Art \& Design lead Educational Programs - Can "Design Thinking" spark new answers to old problems? Annual Conference of the College of Art Association (CAA). New York, NY.

Brown, T. (2008). Design thinking. Harvard Business Review, 86(6), 84-92.

Brown, T. (2016). Design Thinking: Thoughts by Tim Brown - Unlock your Organization's Creative Potential. Retrieved from https://aidesignsolutions.com/2016/09/22/design-thinking-thoughts-by-tim-brown/ 


\section{eJRIEPS Hors Série 4 Juillet 2021}

Buchanan, R. (1992). Wicked Problems in Design Thinking. Design Issues, 8(2), 5-21. The MIT Press. Retrieved from http://www.jstor.org/stable/1511637

Carlgren, L., Elmquist, M., \& Rauth, I., 2016. The Challenges of Using DT in IndustryExperiences from Five Large Firms. Creativity and Innovation Management, 25(3), 344-362.

Chambers, F.C. (2020). Design Thinking: Pedagogy, Process, Mindset and Space. In F.C. Chambers, A. Bryant \& D. Aldous (Eds). Threshold Concepts in Physical Education: A design thinking approach. London: Routledge.

Chambers, F.C. \& Sammon, D. (in press). CUP:ID: Using design thinking to develop policies in higher education. In I. Schmidberger, S. Wipperman, T. Stricker \& U. Müller (Eds): Design Thinking in Education Management - successfully developing and implementing innovations in educational contexts. London: Springer link

Chambers, F.C. (2018). Learning to mentor in sports coaching: A design thinking approach. Oxon, Ox: Routledge.

Cuthbert, B., Vaugh, T., \& Chambers, F.C. (2018). What is design thinking? A case study of using design thinking in a sports coaching context. In F.C. Chambers (Ed.), Learning to Mentor in Sports Coaching: A Design Thinking Approach. London: Routledge

d.school (Producer) (2010). Empathy mapping. Retrieved December 29, 2017 from https://dschool.stanford.edu/ resources/

Dell (2017). The Next Era of Human Machine Partnerships: Emerging Technologies Impact on Society and Work in 2030. Dell: Institute of the Future.

The Design Council (2005). Design Council UK. 2005. The Design Process. Retrieved on $3^{\text {rd }} \quad$ February 2016 from http://www.designcouncil.org.uk/aboutdesign/Howdesigners-work/The-design-process/\%3E

The Design Council (2019). What is the framework for innovation? Design Council's evolved Double Diamond. Retrieved on 1st March 2020 from: https://www.designcouncil.org.uk/news-opinion/what-framework-innovationdesign-councils-evolved-double-diamond

Di Russo, S. (2016). Understanding the behaviour of design thinking in complex environments. Unpublished doctoral thesis, Swinburne University of Technology, Hawthorn, VIC, Australia.

Doorley, S. \& Witthoft, S. (2011). Make Space: How to set the stage for creative collaboration. New York, NY: Wiley. 
eJRIEPS Hors Série 4 Juillet 2021

Dudley, D., Cairney, J., Wainwright, N., Kriellaars, D., ～\& Mitchell, D. (2017). Critical considerations for physical literacy policy in public health, recreation, sport, and education agencies. Quest, 69, 436-452. doi:10.1080/00336297.2016.1268967

Goligorsky, D. (2012). Empathy and Innovation: The IDEO Approach, Lecture. Boston, MA: Harvard Business School.

Groeger, L. Schweitzer, J., Sobel, L., \& Malcom, B. (2019). Adopting a Design Thinking Mindset: Towards a Framework for developing Creative Confidence in Business Students. Academy of Design Innovation Management Conference 19th June. London.

Hassi, L. \& Laakso, M. (2011). Design Thinking in the Management Discourse: Defining the elements of the concept. 18 $18^{\text {th }}$ International Product Development Management Conference, Innovate through Design. Delft, The Netherlands.

Hasso-Plattner Institute (2018). HPI Academy. [Online] Available at: https://hpi.de/en/index.html [Accessed 1405 2018].

Hasso Plattner Institute (2019). HPI Academy. [Online] Available at: https://hpi.de/en/index.html [Accessed $3^{\text {rd }}$ September 2019]

IDEO (2009). Human Centred Design Toolkit. San Francisco, CA: IDEO.

Lawson, B. (2001). The Language of Space. Oxford: Architectural Press.

Liedtka, J. (2015). Perspective: Linking Design Thinking with Innovation Outcomes through Cognitive Bias Reduction. Journal of Product Innovation Management, 32(6), 925938.

Lockwood, T. (2016). Design Thinking. Retrieved from Lockwoodresource.com/insight/design-thinking

Longmuß, J., Höhne, B., Bräutigam, S., Oberländer, A., \& Schindler, F. (2016). Agile Learning - Bridging the Gap between Industry and University. Proceedings of the 44th SEFI Conference. Tampere

Luchs, M.G., Swan, S., \& Griffin, A. (2015). Design Thinking: New Product Development Essentials from the PDMA. London, Wiley.

McCrindle, M. (2019). GenZGenAlpha. Retrieved from

https://mccrindle.com.au/insights/publications/infographics/

Martin, R. (2009). The Design of Business. Boston, MA: Harvard Business School Publishing.

Merck (2018). The State of Curiosity Report. Darmstadt, Germany: Merck. Retrieved from https://www.merckgroup.com/en/company/curiosity/curiosity-report.html 
eJRIEPS Hors Série 4 Juillet 2021

OECD (2019). Trends Shaping Education 2019. Paris: OECD Publishing, https://doi.org/10.1787/trends edu-2019-en.

Peters, B.G. (2017). What is so wicked about wicked problems: A conceptual analysis and research program. Policy and Society, 36(3), 385-396.

Meyer, J.H.F. \& Land, R. (2003). Threshold Concepts and Troublesome Knowledge. Linkages to Ways of Thinking and Practising' in Improving Student Learning - Ten Years On. Oxford: OCSLD.

Norman, D.A. (2002). The Design of Everyday Things. Boston, MA: MIT Press.

Nussbaum, B. (2011). Design Thinking Is A Failed Experiment. So What's Next? Retrieved from

http://www.fastcodesign.com/1663558/design-thinking-is-a-failed-experiment-sowhats-next

Proshansky, H.M., Ittelson, W.H., \& Rivlin, L. (1970). Environmental psychology: Man and his physical setting. . New York, NY: Holt, Rinehart \& Winston.

Rittel, H.W.J. \& Webber, M.M. (1973). Dilemmas in a general theory of planning. Policy Sciences, 4, 155-169.

Sammon, D. (2016). Action Design Approach. University College Cork: Cork University Business School.

Schweitzer, J., Groeger, L., \& Sobel, L. (2016). The Design thinking mindset: An Assessment of What We Know and What We See in Practice. Journal of Design Business \& Society, 2(1), 71-94. 10.1386/dbs.2.1.71 1

Smirnow, C. (2017). Pathways to Gender Identity: An engagement framework for gender inclusivity in educational institutions. New York City, NY: Parsons School of Design.

Shearer, A. W. (2015). Abduction to Argument: A framework for DT. Landscape Journal, 34(2), 128-138.

Sparrow, J. (2018). Digital Fluency: Big, Bold Problems. New Horizons: The technologies ahead. Educause Review. March 12.

Thoring, K., Desmet, P., \& Badke-Schaub, P. (2018). Creative environments for design education and practice: A typology of creative spaces. Design Studies 56(C), 5483.

Whitehead, M. (2007). Physical literacy: Philosophical considerations in relation to developing a sense of self, universality and propositional knowledge. Sport Ethics Philosophy, 1(3), 281-299. 


\section{eJRIEPS Hors Série 4 Juillet 2021}

Whitehead, M. (2013). The history and development of physical literacy. ICSSPE Bulletin Journal of Sport Science and Physical Education, 65, 21-27.

Windahl, C. (2017). Market sense-making in design practice: exploring curiosity, creativity and courage. Journal of Marketing Management, 33(3-4), 280-291.

Womack, J.P. \& Jones, D.T. (2003). Lean Thinking: Banish Waste and Create Wealth in Your Corporation. New York, NY: Simon and Schuster.

Acknowledgement: Thank you all participants of the AIESEP Seminar who used design thinking to unlock key pedagogical considerations for physical literacy. A sincere thank you to Dr David Aldous and Dr Anna Bryant from Cardiff Metropolitan University in Wales for assisting in the smooth running of the workshop. Their help was invaluable. 